\title{
SIMPLIFICATION OF IMMUNE ADHERENCE HEMAGGLUTINATION TEST FOR DETECTION OF RABIES ANTIBODIES IN HUMAN SERUM
}

\begin{abstract}
SUMMARY
In the present work the immune adherence hemagglutination test (IAHA) was standardized in a simplified procedure. This test showed good reproducibility, better than the classical mice serum neutralization test (SN). The tests showed high correlation degree: high titers in one test corresponded to high titers in the other one. and the same occured with low titers. The IAHA test is extremely simple, fast to perform, and of low cost when compared to tests such as SN or indirect immunofluorescense (IIF). It also proved to be useful in less sophisticated laboratories or even as a screening test for the titration of rabies antibodies.
\end{abstract}

KEY WORDS: Immune adherence; Hemagglutination test; Rabies antibodies.

\section{INTRODUCTION}

The immune adherence phenomenon was first described by LAVERAN \& MESNIL ${ }^{9}$ and LEVADITI ${ }^{11}$. Later PEREIRA ${ }^{12}$ and IT'O \& TA GAYA $^{7}$ carried out the first studies in order to apply this test in virological research.

Basically the test consists in activating the complement system through the formation of antigen-antibody complexes resulting in pro duction of the $\mathrm{C} 3 \mathrm{~b}$ component which promotes the agglutination of human erythrocytes. It should be pointed out that only primate ery throcytes show receptors on their surface for the $\mathrm{C} 3 \mathrm{~b}$ fraction.
Several studies showed that the reaction of hemagglutination by immune adherence is more specific and sensitive than complement fixation (CF) test, as well as much simpler to perform ${ }^{3}$ 6. 10. 12 .

Recently LENNETTE \& LENNETTE ${ }^{10}$ stan dardized the immune adherence hemagglutina tion (IAHA) test for several bacterial and viral antigen-antibody systems.

In 1933 BUDZKO et al. ${ }^{2}$ adapted this test for rabies serology, suggesting its use for routine detection and quantification of rabies antibo dies.

(1) Instituto Pasteur de Sāo Paulo. Sào Paulo. SP, Brazil

(2) Disciplina de Imunologia da Escola Paulista de Medicina. Sảo Paulo. SP. Brazil

(3) Disciplina de Medicina Veterinária Preventiva e Saude Animal da Faculdade de Medicina Veterinaria e Zootecnia da Univer sidade de Sāo Paulo. Sáo Paulo. SP. Brazil

Address for correspondence: Carlos Roberto Zanetti. Instituto Pasteur de Sào Paulo. Av. Paulista, 393 . CE.P 01311 Sāo Paulo SP. Brazil 
ZANETTI, C. R.; TINO, M. S.; CHAMELET, E. L. B.; ISHIZUKA, M. M. \& PEREIRA, O. A. de C. - Simplification of immune adherence hemagglutination test for detection of rabies antibodies in human serum. Rev. Inst. Med. trop. S. Paulo, $31(5): 341345,1989$.

The objective of the present study was to adapt a simplified procedure for IAHA test to detect and titrate antirabies antibodies in human sera, comparing it with the serum neutrali zation ( $\mathrm{SN}$ ) test, wich is the most commonly used among us ${ }^{1}$.

\section{MATERIALS AND METHODS}

1.-Sera: Thirty samples of human sera were analyzed in order to estimate the reproducibility of IAHA simplified method as compared to the original one. Another 35 samples were evaluated in duplicates (double-blind) in order to compare the IAHA by the simplified method with the SN The results were quantitative and qualitative analyzed.

2 - Antigens: Antigen and control antigen was obtained from Pfizer Quimica Ltda - São Paulo, Brasil. Briefly, fixed rabies virus cultured in bovine kidney cells were inactived by $\boldsymbol{\beta}$-pro piolactone and purified as previously described ${ }^{5}$. Titers were determined by block titrations prior to use.

3 - Complement: Fresh guinea-pig serum was used as source of complement. The comple ment was stored at $-70^{\circ} \mathrm{C}$ in small portions after was reconstituted.

4 - Diluents: Kolmer saline ${ }^{8}$, Veronal buffer saline (VBS), Gelatin-Veronal buffer (GVB), Bovine serum albumin-Veronal buffer (A-VBS), Dithiothreitol-ethilenediaminetetraacetic acid VBS (D-VBS)

5 - Erythrocytes: Twenty human blood samples were collected in equal volume of sterile Alsever solution from known type " $O$ " donnors and than stored at $4^{\circ} \mathrm{C}$ for up 5 weeks. These samples were tested, since the test is known to vary with erythrocytes from different donnors. A human serum known to be positive for rabies antibodies was reagent up to 1:80 or 1:160 dilutions in the presence of 14 of the 20 erythrocytes samples tested. With four out of the remaining 6 erythrocytes samples, serum showed lower ti ters and was non reagent with two of them. Immediately prior to use, the erythrocytes were wa shed twice in Kolmer saline and than resuspen ded to a concentration of $1 \%$ in Kolmer saline.
6 - Original technique: The IAHA method was performed as described by LENNETTE \& LENNETTE ${ }^{10}$.

7 - Modified technique: The simplified tech nique was based on the original technique with few modifications. Briefly, equal volumes $(0.025$ $\mathrm{ml}$ ) of serial dilutions of serum and rabies anti gen $(1: 15)$ were incubated in 96 -well plastic plates (Petecil) at $37^{\circ} \mathrm{C}$ for 30 minutes. After adding $0.025 \mathrm{ml}$ of a 1:120 dilution of fresh guinea pig serum, the mixture was further incubated at 37 "C for 40 minutes. A human type " $O$ " ery thro cyte suspension $(0.025 \mathrm{ml})$ was then added and the plates were allowed to stand at room tempe rature for 2 hours. The hemagglutination pattern was read, and the titers were recorded as the reciprocal of the highest serum dilution showing positive agglutination.

Each test was always performed with proper controls of serum, antigen, complement and erythrocytes.

Results were considered as positives when the patterns of hemagglutination obtained were $3+$ or $4+$ (plus) and negative or absent in con trols.

8 - Serum neutralization test: This test was performed essentially as described by ATANASIU $^{1}$, with sera diluted up to 1:625. All tests were performed against $25-40 \mathrm{LD}_{50}$ and titer values $<5$ were considered negative.

\section{RESULTS}

Comparison between the Veronal buffer and the Kolmer solution: Table 1 shows a comparison between the IAHA procedure performed with Veronal buffer with $0.1 \%$ BSA (Bovine Serum Albumin), Kolmer solution with $0.1 \%$ and $0.01 \%$ BSA and Kolmer solution without BSA.

Total agreement was observed among the titers of the 30 sera tested with all diluents ex cept when the serum albumin was completely removed from the Kolmer solution, when the occurence of nonspecific agglutination was observed. 
ZANETTT, C. R.; TINO, M. S.; CHAMELET, E. L. B.; ISHIZUKA, M. M. \& PEREIRA, O. A. de C. - Simplification of immune adherence hemagglutination test for detection of rabies antibodies in human serum. Rev. Inst. Med. trop. S. Paulo, 31(5): 341-345, 1989.

TABLE 1

Evaluation of four different diluents in the Immune Adherence Hemagglutination Test (IAHA) for antirabies antibodies titra tion in vaccinated and non-vaccinated persons.

\begin{tabular}{|c|c|c|c|c|}
\hline & \multicolumn{4}{|c|}{ DILUENT } \\
\hline & V $0.1 \%$ & $\mathrm{KO} 0.1 \%$ & $\mathrm{~K} 0.01 \%$ & $\mathrm{~K}-$ \\
\hline \multirow{22}{*}{ 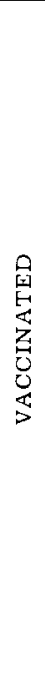 } & 20 & 20 & 20 & 80 \\
\hline & 40 & 40 & 40 & 160 \\
\hline & 80 & 80 & 80 & 160 \\
\hline & 160 & 160 & 160 & 640 \\
\hline & 40 & 40 & 40 & 80 \\
\hline & 160 & 160 & 160 & 640 \\
\hline & 640 & 640 & 640 & 640 \\
\hline & 40 & 40 & 40 & 80 \\
\hline & 20 & 20 & 20 & 80 \\
\hline & 20 & 20 & 20 & 80 \\
\hline & 80 & 80 & 80 & 160 \\
\hline & 80 & 80 & 80 & 320 \\
\hline & 80 & 80 & 80 & 320 \\
\hline & 80 & 80 & 80 & 320 \\
\hline & 320 & 320 & 320 & 640 \\
\hline & 160 & 160 & 160 & 640 \\
\hline & 40 & 40 & 40 & 80 \\
\hline & 40 & 40 & 40 & 80 \\
\hline & 20 & 20 & 20 & 80 \\
\hline & 80 & 80 & 80 & 160 \\
\hline & 160 & 160 & 160 & 640 \\
\hline & 80 & 80 & 80 & 320 \\
\hline \multirow{8}{*}{ 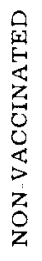 } & 5 & 5 & 5 & 20 \\
\hline & 5 & 5 & 5 & 40 \\
\hline & 5 & 5 & 5 & 20 \\
\hline & 5 & 5 & 5 & 40 \\
\hline & 5 & 5 & 5 & 40 \\
\hline & 5 & 5 & 5 & 40 \\
\hline & 5 & 5 & 5 & 80 \\
\hline & 5 & 5 & 5 & 40 \\
\hline
\end{tabular}

$\mathrm{V}=$ Veronal buffer + pereentage of $\mathrm{BSA}$

$\mathbf{K}=$ Kolmer saline + percentage of BSA

$\mathbf{K}-=$ Kolmer saline without BSA

For qualitative analysis of the results the YULE association coeficient was calculated and its value was 1 (one). The agreement of the antibody titers of tested sera with Veronal buffer plus $0.1 \%$ BSA, Kolmer solution plus $0.1 \%$ and $0.01 \%$ BSA was $100 \%(30 / 30)$.

Comparison between IAHA and SN reproducibility: Thirty five human sera were analyzed in duplicates (double-blind) and the qualitative analysis of the results were performed.

On the basis of these results the Yule association coeficient was calculated for the IAHA and the $\mathrm{SN}$ tests, both values being equal to 1 (one). The agreement were calculated from the values of the antibody titers of sera in duplicates.
TABLE 2

Comparison of Immune Adherence Hemagglutination Test (IAHA) and Serum Neutralization Test ( $\mathrm{SN}$ ) in antirabies anti. bodies titration in vaccinated and non vaccinated persons by double-blind assay of serum duplicates.

\begin{tabular}{|c|c|c|c|c|}
\hline & \multicolumn{2}{|c|}{ IAHA } & \multicolumn{2}{|c|}{$\mathrm{SN}$} \\
\hline & \multicolumn{2}{|c|}{ Samples } & \multicolumn{2}{|c|}{ Samples } \\
\hline & 1st aliquot & 2nd aliquot & 1st aliquot & 2nd aliquot \\
\hline \multirow{21}{*}{ 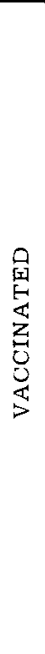 } & 40 & 40 & 67 & 25 \\
\hline & 40 & 40 & 32 & 625 \\
\hline & 40 & 80 & 158 & 125 \\
\hline & 40 & 40 & 10 & 19 \\
\hline & 80 & 80 & 32 & 25 \\
\hline & 80 & 40 & 158 & 83 \\
\hline & 80 & 40 & 275 & 151 \\
\hline & 40 & 40 & 51 & 54 \\
\hline & 20 & 20 & 57 & 25 \\
\hline & 40 & 40 & 275 & 95 \\
\hline & 40 & 40 & 54 & 323 \\
\hline & 20 & 20 & 46 & 166 \\
\hline & 40 & 40 & 12 & 13 \\
\hline & 80 & 80 & 223 & 625 \\
\hline & 5 & 5 & 57 & 5 \\
\hline & 160 & 160 & 331 & 625 \\
\hline & 160 & 80 & 625 & 625 \\
\hline & 320 & 640 & 625 & 467 \\
\hline & 160 & 160 & 331 & 20 \\
\hline & 320 & 320 & 625 & 625 \\
\hline & 320 & 640 & 625 & 625 \\
\hline \multirow{14}{*}{ 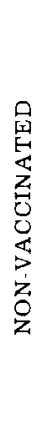 } & 5 & 5 & 5 & 5 \\
\hline & 5 & 5 & 5 & 5 \\
\hline & 5 & 5 & 5 & 5 \\
\hline & 5 & 5 & 5 & 5 \\
\hline & 5 & 5 & 5 & 5 \\
\hline & 5 & 5 & 5 & 5 \\
\hline & 5 & 5 & 5 & 5 \\
\hline & 5 & 5 & 5 & 5 \\
\hline & 5 & 5 & 5 & 5 \\
\hline & 5 & 5 & 5 & 5 \\
\hline & 5 & 5 & 5 & 5 \\
\hline & 5 & 5 & 5 & 5 \\
\hline & 5 & 5 & 5 & 5 \\
\hline & 5 & 5 & 5 & 5 \\
\hline
\end{tabular}

Thus, for the IAHA test there is an agreement of $70 \%(14 / 20)$, whereas the other $30 \%$ showed a discrepancy of only one dilution. For SN there was an agreement of $47 \%(10 / 21)$, a discrepancy of 1 dilution interval in $43 \%(9 / 21)$ and of 2 dilu tion intervals in $10 \%$ of the cases $(2 / 21)$.

Correlation between IAHA and SN: Still based on table 2 data, the Spearman correlation coeficient was calculated, with the antibody titers of the first duplicate of both tests. This coeficient was 0.76 and its significance was estimated by Student test (5.23) that was significant at the 
ZANETTI, C. R.; TINO. M. S.: CHAMELET. E. L. B.: ISHIZUKA. M. M. \& PEREIRA, O. A. de C. - Simplification of immune adherence hemagglutination test for detection of rabies antibodies in human serum. Rev. Inst. Med. trop. S. Paulo, 31(5): 341 345. 1989

reject level adopted $(=0.05)$, for 21 degrees of freedon $(t=2.080)$.

\section{DISCUSSION}

The simplified IAHA test here presented proved to be highly satisfactory as an alternative method for rabies antibody titration. Compared to the classical SN test the IAHA test showed much greater reproducibility. Similar results in duplicated tests were observed in $70 \%$ and $47 \%$ of serum samples tested by IAHA and SN tests respectively. The remaining $30 \%$ of the samples tested by IAHA procedure showed differences in the titers corresponding to only one double dilution. In the SN test $43 \%$ of the samples sho wed discrepancy of 1 interval of five fold dilution, $10 \%$ of them showed discrepancy of 2 intervals.

The Spearman correlation coeficient indica ted that the antibody titers mesured simultaneously by the SN and IAHA tests showed high correlation, i.e., high titers in SN test correspond to high titers in IAHA test and conversely, low titers in SN test correspond to low titers in IAHA test. It can be also noted that this test is much more easily performed, the result being obtained in an average period of 4 hours, while the SN test required the observation of the animals for 2 or 3 weeks

One out of the sera studied in duplicates presented negative result by IAHA while positive result was obtained by $\mathrm{SN}$ even though with low titer (Table 2). Positively of this serum was con firmed by indirect immunofluorescence proce dure ${ }^{\ddagger}$.

In its original description ${ }^{3}$ the IAHA test is performed with Veronal buffer. In the present study the Veronal buffer was replaced by the Kolmer solution, which is basically a saline solu tion with the addition of magnesium. The stages of plate coating with gelatin and of interruption of the reaction with EDTA-Dithiothreitol were eliminated too. These modifications greatly reduced the costs of performing the test, with no impairment to results.

In can be noted in Table 2 that the 10 fold reduction in $\mathrm{BSA}$ concentration in the diluent (from $0.1 \%$ to $0.01 \%$ ) does not alter the results either, reducing even further the cost of the test. Total elimination of the BSA was not possible though, since it caused false hemagglutination patterns.

It has been stated by LENNETTE \& LENNETTE $^{10}$ that only erythrocytes from one donnor out of three give suitable results in the IAHA test. In our work 14 out of 20 erythrocytes tested were satisfactory. Lower titers were obtai. ned with the remainder ones. This difference found in the frequence of usable erythrocytes in the IAHA test in our work and in the LENNETTE \& LENNETTE one, might be due to differences in the receptors concentration for $\mathrm{C} 3 \mathrm{~b}$ in the erythrocytes of the two studied popula tions.

We believe that the results obtained should recommend the inclusion of this test for routine use the detection and titration of rabies antibodies.

\section{RESUMO}

\section{Simplificação da Reação de Hemaglutinação por Imunoaderência para detecção de anticor- pos anti-rabicos em soros humanos.}

A Reação de Hemaglutinação por Imunoa derencia foi padronizada de maneira simplifica da, para detecção de anticorpos rábicos em soros humanos. Esta reação mostrou grande reprodu tibilidade, maior que a apresentada pela clássica prova de soroneutralização em camundongos (SN).

Ambas as provas mostraram alto grau de correlação, ou seja, altos títulos em uma reação correspondeu a altos títulos na outra; o mesmo ocorreu em relaçảo aos títulos baixos.

A reação de Hemaglutinação por Imunoade rência, além de ser de execução extremamente simples e rápida, tem custo bem menor se com parada a provas como a soroneutralizaçào ou a imunofluorescencia indireta. Pode, portanto, ser de grande utilidade em laboratórios com poucos recursos ou mesmo ser utilizada como uma prova de triagem para a titulação de anticorpos rábicos. 
ZANETTI, C. R.: TINO, M. S.; CHAMELET, E. L. B.; ISHIZUKA, M. M. \& PEREIRA, O. A. de C. - Simplification of immune adherence hemagglutination test for detection of rabies antibodies in human serum. Rev. Inst. Med. trop. S. Paulo, 31(5): 341 345, 1989.

\section{ACKNOWLEDGEMENTS}

The authors wish to thank Dr. Flávio Zelante from Pfizer Quimica Ltda., for providing rabies antigens. This work was supported by CNPq, CAPES and FINEP.

\section{REFERENCES}

1. ATANASIU. P. - Titrage des anticorps rabiques pratiqué sur les sérums humains. Bull. Off. int. Epiz., 67(34): 383387,1967

2. BUDZKO, D, B.: CHARAMELA, L. J.: JELINEK, D. \& ANDERSON, G. R - Rapid test for detection of rabies antibodies in human serum. J. clin. Microbiol., 17: 481484 . 1983.

3. GERSHON, A.: KALTER, Z. G. \& STEINBERG, S. Detection of antibody to varicella zoster virus by immune adherence hemagglutination. Proc. Soc. exp. Biol. (N.Y.), 151: $762-765,1976$

4. GOLDWASSER, R. A. \& KISSLING, R. E. .. Fluorescent antibody staining of street and fixed rabies virus antigens. Proc. Soc. exp. Biol. (N.Y.), 98: $219223,1958$.

5. GUIDOLIN, R.; BALTAZAR, M. C. \& ZELANTE, F. Produçào da vacina anti rabica veterinăria em suspensāo de células BHK. Rev. Microbiol. (S. Paulo), 14: 27 35, 1983.
6. INOUYE, S.: MATSUNO. S.: HASEGAWA. A : MYAMU RA, K.; KONO, R. \& ROSEN. L - Serotyping of dengut viruses by immune adherence hemagglutination test Amer. J. trop. Med. Hyg., 29: 1389.1393, 1980.

7. ITO, M. \& TAGAYA, I. - Immune adherence hemaggluti nation test as a new sensitive method for titration of ani mal viruses antigens and antibodies. Jap. J. med. Sci Biol., 19: 109 126, 1966.

8. KOLMER, J. A. - The tecnique of the Kolmer comple ment fixation test for syphilis employing one fifth amount of reagents. Amer. J. clin. Path., 12: 109.112, 1942

9. LAVERAN, A. \& MESNIL, F .- Recherches morpholo giques et expérimentales sur le tryparosome des rats Ann. Inst. Pasteur, 15: 673-714. 1901.

10. LENNETTE. E. T. \& LENNETTE. D. A. - Immune adhe rence hemagglutination alternative to complement fixa tion serology. J. clin. Microbiol., z: 282285.1978.

11. LEVADITI. C. - Sur l'état de la cytase dans le plasma des animaux normaux et des organismes vaccinés contre le vibrion cholerique. Ann. Inst. Pasteur, 15: 894 927. 190 ]

12. PEREIRA. O. A. C. - The use of immune adherence reac tion in the study of some Brazilian arboviruses Rev. Inst. Med. trop. S. Paulo, 8: 41.52, 1966.

Recebido para publicaçāo cm 741989 